OPEN

SUBJECT AREAS:

QUANTUM DOTS

CANCER IMAGING

NANOPARTICLES

ANALYTICAL CHEMISTRY

Received

15 August 2013

Accepted

12 September 2013

Published

2 October 2013

Correspondence and requests for materials should be addressed to N.M. (nan.ma@suda. edu.cn)

\title{
One-Step Instant Synthesis of Protein-Conjugated Quantum Dots at Room Temperature
}

\author{
Xuewen He, Li Gao \& Nan Ma
}

The Key Lab of Health Chemistry and Molecular Diagnosis of Suzhou, College of Chemistry, Chemical Engineering and Materials Science Soochow University, Suzhou, 215123, P. R. China.

We present a new general facile strategy for the preparation of protein-functionalized QDs in a single step at ambient conditions. We demonstrated that highly luminescent red to near-infrared (NIR) protein-functionalized QDs could be synthesized at room temperature in one second through a one-pot reaction that proceeds in aqueous solution. Herein protein-functionalized QDs were successfully constructed for a variety of proteins with a wide range of molecular weights and isoelectric points. The as-prepared protein-conjugated QDs exhibited high quantum yield, high photostabiliy and colloidal stability, and high functionalization efficiency. Importantly, the proteins attached to the QDs maintain their biological activities and are capable of catalyzing reactions and biotargeting. In particular, the as-prepared transferrin-QDs could be used to label cancer cells with high specificity. Moreover, we demonstrated that this synthetic strategy could be extended to prepare QDs functionalized with folic acids and peptides, which were also successfully applied to cancer cell imaging.

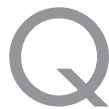

uantum dots are superior luminophores with large extinction coefficient, strong photoluminescence, and robust photostability, which have proven to be powerful tools for bioimaging and biosensing ${ }^{1-12}$.

Proteins represent a central target in medical and biochemical research. Fluorescent labeling of proteins provides a useful means to explore the roles of proteins in fundamental biological processes and implement a variety of biomedical applications such as optical imaging and biosensing ${ }^{6,7,9,12,13}$. However, preparation of protein-conjugated QDs is a laborious multi-step process that usually consists of colloidal QDs synthesis, QDs solubilization, and biomolecule functionalization ${ }^{4,5,7,8,14-16}$. The stringent reaction conditions and synthetic complexities would prohibit the end-users from gaining direct access to customizable QD probes in an easy and efficient manner. So far direct aqueous synthesis of protein-conjugated QDs at ambient conditions has achieved little success in producing highly luminescent QDs that are competent for bioimaging applications ${ }^{17-19}$.

In order to achieve one-step synthesis of protein-functionalized QDs, we developed a QD synthetic strategy that meets the following criteria: (i) the QDs should be enriched with certain metal ions that can coordinate with various amino acid functional groups (e.g. carboxyl group; amino group; thiol group, imidazole et al.), leading to effective binding of the protein with QD surface ${ }^{20}$; (ii) the QDs synthesis reaction should proceed at ambient conditions (i.e. room temperature) rapidly to avoid protein denaturing; (iii) the as-prepared QDs should possess suitable emission range, high quantum yield (QY), and high photostability for bioimaging applications. Although DNA-functionalized CdTe QDs have been successfully constructed via a one-step strategy ${ }^{21,22}$, the high temperature $\left(100^{\circ} \mathrm{C}\right)$ and long reaction time (1 hour) required to synthesize CdTe QDs could not be applied to directly prepare protein-functionalized QDs since protein molecules would be easily denatured at high temperatures.

\section{Results}

In this study we report a new type of alloyed $\mathrm{Zn}_{\mathrm{x}} \mathrm{Hg}_{1-\mathrm{x}} \mathrm{Se}$ QDs that fully meet the criteria for one-step synthesis of protein-functionalized QDs. The synthesis of $\mathrm{Zn}_{\mathrm{x}} \mathrm{Hg}_{1-\mathrm{x}} \mathrm{Se} \mathrm{QDs}$ is conducted in aqueous solution at room temperature and completed in one second, which surpasses the main obstacle for one-step preparation of protein-functionalized QDs. In particular, the as-prepared $\mathrm{Zn}_{\mathrm{x}} \mathrm{Hg}_{1-\mathrm{x}} \mathrm{Se}$ QDs exhibiting strong red to NIR photoluminescence that is suitable for bioimaging, which can hardly be achieved for other types of QDs produced with the same synthetic strategy. Moreover, the $\mathrm{Zn}^{2+}$ ion could coordinate with a variety of amino acid residues (e.g. Asp/ Glu (carboxyl group), His (imidazole), Tyr (hydroxyl group), Lys (amino group), and Cys (thiol group)) $)^{23,24}$, which would lead to effective binding of protein with zinc-based QDs. In this QD synthesis regime protein molecules 
and small thiol-containing molecules (e.g. mercaptopropionic acid (MPA)) are both used as ligands simultaneously to generate proteinfunctionalized QDs (Figure 1). While protein molecules would bind to the QDs through the coordination of amino acid residues with $\mathrm{Zn}^{2+}$ ions on QD surface ${ }^{23,24}$, the small thiol-containing MPA molecules would serve as additive QD ligands to achieve good surface passivation and optimal photoluminescence properties ${ }^{22}$. As a starting point, we first explore the synthesis of unfunctionalized $\mathrm{Zn}_{\mathrm{x}} \mathrm{Hg}_{1-\mathrm{x}} \mathrm{Se}$ QDs using MPA as ligands and $\mathrm{Zn}(\mathrm{OAc})_{2}, \mathrm{Hg}\left(\mathrm{ClO}_{4}\right)_{2}$, and $\mathrm{NaHSe}$ as precursors. In brief, $\mathrm{Zn}(\mathrm{OAc})_{2}, \mathrm{Hg}\left(\mathrm{ClO}_{4}\right)_{2}$, and MPA are first mixed in $\mathrm{NH}_{4} \mathrm{HCO}_{3}$ solution $(\mathrm{pH}$ 12.3) after which $\mathrm{NaHSe}$ is quickly injected into the mixture followed by vortexing (see experimental section for more details). The reaction mixture turned brown immediately after injecting NaHSe (Figure 2), indicating instant formation of QDs. Different $\mathrm{Hg} / \mathrm{Zn}$ precursor molar ratios (1\%, $2 \%, 5 \%, 10 \%, 20 \%, 25 \%, 40 \%)$ were used for QD synthesis, as the $\mathrm{Hg} / \mathrm{Zn}$ precursor ratio increases the absorption spectra and emission spectra of the as-prepared QDs both shifted to longer wavelength (SI section 1.1). The emission maximum shifted from $672 \mathrm{~nm}$ to $907 \mathrm{~nm}$ as the $\mathrm{Hg} / \mathrm{Zn}$ precursor ratio increased from $1 \%$ to $40 \%$. The QDs synthesized at $\mathrm{Hg} / \mathrm{Zn}$ precursor ratio of $10 \%$ exhibit the highest quantum yield $(\mathrm{QY}=25.6 \%)$ and an emission maximum at $704 \mathrm{~nm}$ (Table 1 and Figure 2). The size and morphology of the asprepared QDs $(\mathrm{Hg} / \mathrm{Zn}$ precursor ratio of $10 \%)$ were characterized using transmission electron microscopy (TEM). Near monodisperse spherical nanoparticles were obtained with a mean diameter of $4.0 \pm$ $0.6 \mathrm{~nm}$ (Figure $2 \mathrm{~d}$ ). Lattice fringes can be clearly visualized in highresolution TEM images, indicating the formation of nanocrystalline materials. STEM-EELS analysis confirms that the as-prepared $\mathrm{Zn}_{\mathrm{x}} \mathrm{Hg}_{1-\mathrm{x}} \mathrm{Se} \mathrm{QDs}$ possess an alloy structure rather than a core-shell structure (SI section 2.1). The broad absorption spectrum of these $\mathrm{Zn}_{\mathrm{x}} \mathrm{Hg}_{1-\mathrm{x}} \mathrm{Se} \mathrm{QDs}$ indicates that the QDs are inhomogeneous alloys ${ }^{25}$. The elemental composition and the $\mathrm{Zn} / \mathrm{Hg} / \mathrm{Se}$ molar ratio in the asprepared QDs were measured using inductively coupled plasma optical emission spectrometry (ICP-OES). The percentage of $\mathrm{Hg}$ incorporated into the QDs increases with elevated $\mathrm{Hg} / \mathrm{Zn}$ precursor ratio (Table 1). The $\mathrm{Zn} / \mathrm{Hg} / \mathrm{Se}$ element molar ratio is $0.91: 0.09: 0.38$ for the QDs synthesized at $\mathrm{Hg} / \mathrm{Zn}$ precursor ratio of $10 \%$. In order to obtain QDs with highest QY, in the following studies all the $\mathrm{Zn}_{\mathrm{x}} \mathrm{Hg}_{1-\mathrm{x}} \mathrm{Se} \mathrm{QDs}$ were synthesized at $\mathrm{Hg} / \mathrm{Zn}$ precursor ratio of $10 \%$.

Next, we proceed to investigate one-step synthesis of proteinfunctionalized QDs based on the above synthetic strategy. We first selected bovine serum albumin (BSA) as a proof-of-concept study. BSA has a molecular weight (M.W.) of $66.4 \mathrm{kDa}$ and an isoelectric point ( $\mathrm{pI}$ ) of 5.3. To synthesize BSA-functionalized $\mathrm{Zn}_{\mathrm{x}} \mathrm{Hg}_{1-\mathrm{x}} \mathrm{Se}$ QDs, BSA and MPA were used as co-ligands and the other reaction conditions were the same as unfunctionalized MPA-QDs. To explore the effects of protein concentration on QD functionalization efficiencies, five different BSA concentrations $(0.25,0.5,1.0,2.0$, and $5.0 \mathrm{mg} / \mathrm{mL})$ were tested for the syntheses. As shown in Figure $2 \mathrm{a}$ and $2 \mathrm{~b}$, there are slightly blue shifts of the absorption and emission spectra of BSAQDs (5.0 $\mathrm{mg} / \mathrm{mL} \mathrm{BSA}$ ) in comparison with unfunctionalized MPAQDs. The photoluminescence intensity of BSA-QDs is almost same as MPA-QDs. The QY of BSA-QDs is $26.0 \%$. These BSA-QDs have a mean diameter of $3.9 \pm 0.5 \mathrm{~nm}$ and near spherical shape illustrated by TEM images (Figure 2d), which is quite analogous to MPA-QDs. QD functionalization with BSA was monitored using agarose gel electrophoresis since the photoluminescence of QDs can be directly detected. As shown in Figure 2e, the unfunctionalized QDs exhibit a single band with high mobility. The QDs synthesized with BSA exhibit an additional band with retarded mobility which is caused by the increased overall size of QDs after BSA functionalization. As the BSA concentration increases the luminescence intensity of the upper band increases while the luminescence intensity of the lower band decreases, indicating that a higher percentage of QDs can be functionalized with increasing BSA concentration. Most of QDs were functionalized with BSA at a BSA concentration of $5.0 \mathrm{mg} / \mathrm{mL}$. To further confirm the presence of BSA on the QDs, the agarose gel was stained with Coomassie brilliant blue. A series of blue bands can be visualized in the stained gel which completely co-localize with the upper QDs bands in the luminescence gel image, confirming the successful attachment of BSA to QDs (Figure 2e). Pure BSA-QD conjugates can be isolated and extracted from the agarose gel without affecting their integrality (SI section 4.2). Gel filtration chromatography (GFC) was also used to monitor QD functionalization in order to precisely measure the hydrodynamic (HD) size of the QDs and quantitate the fraction of protein-functionalized QDs. As shown in Figure 3, the unfunctionalized MPA-QDs exhibit a small hydrodynamic diameter of $\sim 5.4 \mathrm{~nm}$ and a relatively narrow size distribution. The peak of BSA-QDs $(5.0 \mathrm{mg} / \mathrm{mL} \mathrm{BSA})$ shifts to shorter elution time corresponding to a larger hydrodynamic diameter $(\sim 12.1 \mathrm{~nm})$ as a result of the attachment of BSA to the QDs. The fraction of functionalized QDs is calculated to be $95 \%$. The hydrodynamic diameters of MPA-QDs and BSA-QDs measured by dynamic light scattering (DLS) were $5.9 \mathrm{~nm}$ and $13.7 \mathrm{~nm}$ respectively, which are consistent with gel filtration chromatography results (SI section 2.5). The effects of QD on BSA structure were explored using circular dichroism (CD). Little changes were observed for the secondary structure of QD-associated BSA as compared to the native BSA (SI section 4.3). To explore whether the protein itself participates in the QD synthesis, we used BSA $(5.0 \mathrm{mg} / \mathrm{mL})$ as the only ligand to synthesize $\mathrm{Zn}_{\mathrm{x}} \mathrm{Hg}_{1-\mathrm{x}} \mathrm{Se}$ QDs. The QD formation with only BSA molecules is as efficient as that with both BSA and MPA molecules as revealed by the QD absorption spectra (SI section 1.2). In contrast, no QDs were produced in the absence of BSA and MPA molecules. TEM image further confirms the production of nanocrystalline QDs in the presence of only BSA molecules (SI section 2.2). These results suggest that BSA can indeed mediate the growth of QDs and attach to the QDs in a single step process. It is noteworthy that the photoluminescence intensity of the QDs produced with only BSA molecules is quite low due to insufficient surface passivation. The QD photoluminescence intensity can be drastically increased when MPA molecules are used as additive ligands for QD synthesis to improve QD surface passivation (SI section 1.2). The mechanism of BSAmediated QD formation is explored by FTIR, UV-Vis spectroscopy, and TEM (SI section 6). The results show that the protein-directed QD synthesis undergoes the following mechanism: protein molecules first bind to metal ions to form a complex; this complex facilitates controlled nucleation following the introduction of anion precursors; the as-formed nuclei grow bigger to form QDs by reacting with the free precursors in solution; the protein passivates on QD surface once the QD is formed.

To further deconvolute the role of each type of amino acid residue in QD attachment, we performed selective chemical modification of each type of amino acid residue (amino group, thiol group, carboxyl group, imidazole group, hydroxyl group) in BSA in order to block their interaction with the QD respectively. Then we used each chemically modified BSA to synthesize QDs and quantitate the protein functionalization efficiency for the QDs to find out the contribution of each type of amino acid residue to protein attachment. Our results show that the carboxyl group, imidazole group, and hydroxyl group play an important role in protein attachment. Cysteine residues have almost no effect on protein attachment since most of cysteine residues form disulfide bonds in proteins (SI section 5). It is noteworthy that the occurrences of Asp/Glu (-COOH), His (imidazole), and Tyr $(-\mathrm{OH})$ residues within BSA and a large protein population (105990 sequences) are at similar levels. Also, most of these hydrophipic residues are present on protein surface ${ }^{26}$ and would be accessible for QD binding (SI section 5.4). Therefore, it is expectable that this QD synthetic strategy could be used for many other proteins.

To explore whether this QD synthetic strategy could serve as a general strategy to produce protein-functionalized QDs, we tested a 


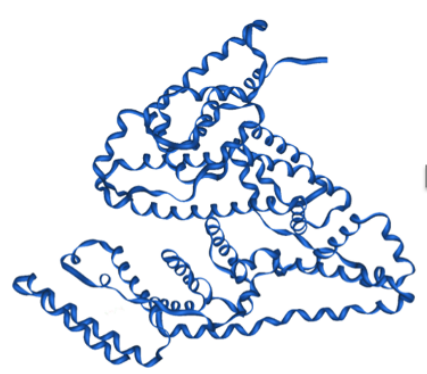

Protein

b

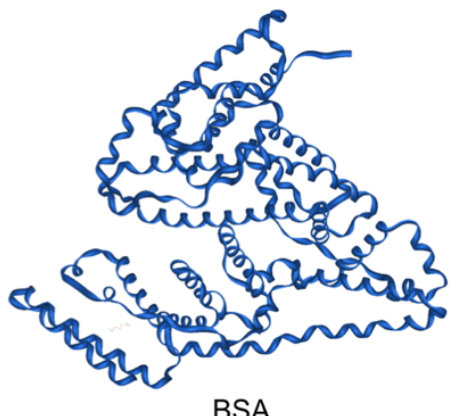

(66.4 kDa, pl=5.3)

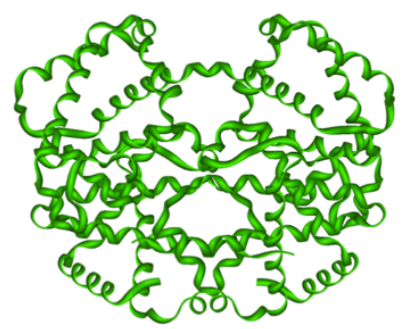

Hemoglobin (64.5 kDa, pl=6.8)
$\mathrm{Zn}^{2+}, \mathrm{Hg}^{2+}, \mathrm{HSe}^{-}$ MPA

room temperature 1 second

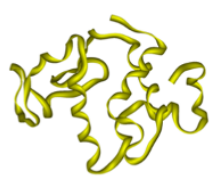

Lysozyme (14.3 kDa, pl=11.4)

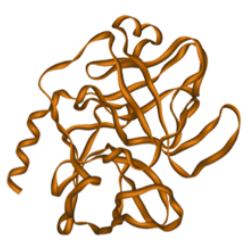

Trypsin $(24 \mathrm{kDa}, \mathrm{pl}=10.1)$

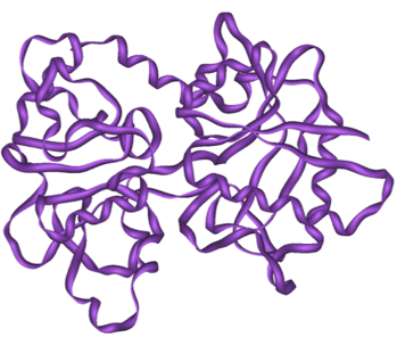

Transferrin ( $80 \mathrm{kDa}, \mathrm{pl}=5.6$ )

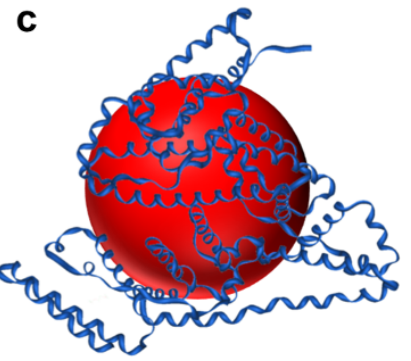

BSA-QD

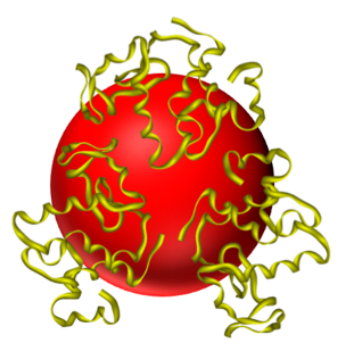

Lysozyme-QD

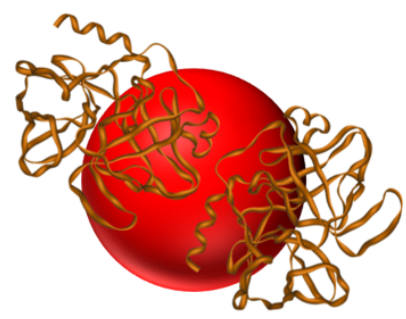

Trypsin-QD

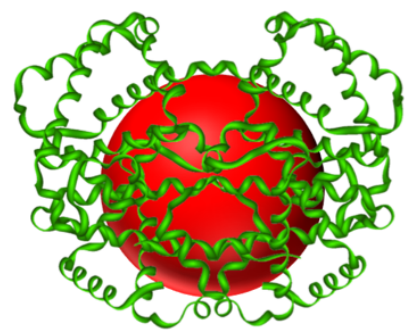

Hemoglobin-QD

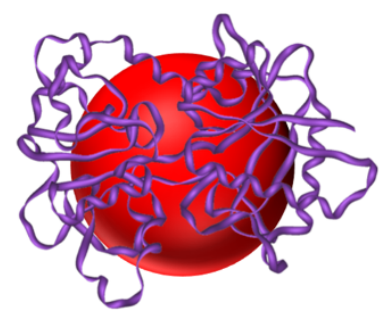

Transferrin-QD

Figure 1 Schematic illustration of one-step preparation of protein-functionalized QDs. (a) One-step synthesis of protein-functionalized $\mathrm{Zn}_{\mathrm{x}} \mathrm{Hg}_{1-\mathrm{x}} \mathrm{Se}$ QDs using $\mathrm{Zn}^{2+}, \mathrm{Hg}^{2+}$, and $\mathrm{HSe}^{-}$ions as precursors and MPA and protein as co-ligands. The synthesis is conducted at room temperature and completed in one second. (b) Structures, molecular weights, and isoelectric points of BSA, lysozyme, trypsin, hemoglobin, and transferrin. (c) Schematic illustration of BSA-, lysozyme-, trypsin-, hemoglobin-, and transferrin-functionalized QDs. 

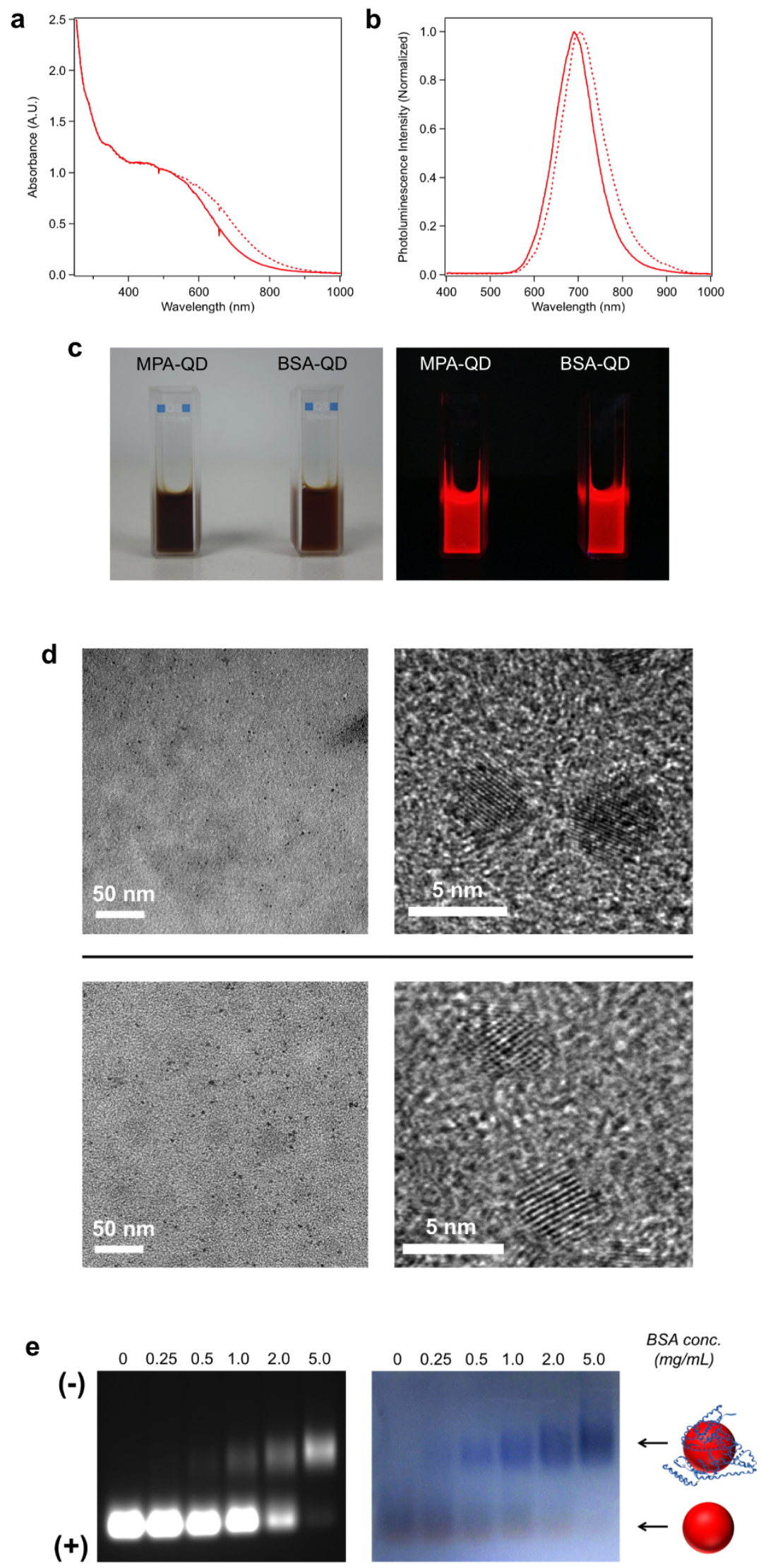

Figure $2 \mid$ Characterization of unfunctionalized MPA-QDs and BSA-functionalized QDs (5.0 mg/mL BSA). (a) Absorption spectra of MPA-QDs (dashed line) and BSA-QDs (solid line). (b) Photoluminescence spectra of MPA-QDs (dashed line) and BSA-QDs (solid line). (c) Photographs of MPA-QDs and BSA-QDs captured under visible light (left) and UV light (365 nm) (right). (d) Low magnification and high-resolution TEM images of MPA-QDs (upper panel) and BSA-QDs (lower panel). (e) Agarose gel electrophoresis of MPA-QDs and BSA-QDs synthesized at different BSA concentrations. The left gel image is the QD photoluminescence image. The right gel image is Coomassie brilliant blue-stained image showing the position of BSA (blue bands). 
Table 1 | Elemental analysis, quantum yields, emission maxima, and FWHM of $\mathrm{Zn}_{x} \mathrm{Hg}_{1-x} \mathrm{Se}$ QDs synthesized at different $\mathrm{Hg} / \mathrm{Zn}$ precursor molar ratios

\begin{tabular}{ccccccc} 
& $\mathrm{Hg} / \mathrm{Zn}$ precursor molar ratio & $\mathrm{Hg} / \mathrm{Zn}$ molar ratio in QD & $\mathrm{Zn} / \mathrm{Hg} / \mathrm{Se}$ molar ratio in QD & QY & $\lambda_{\text {max }}(\mathrm{nm})$ & $\mathrm{FWHM}(\mathrm{nm})$ \\
\hline 1 & $1 \%$ & $4.2 \%$ & $0.96: 0.04: 0.51$ & $13.1 \%$ & 672 \\
2 & $2 \%$ & $4.7 \%$ & $0.95: 0.05: 0.50$ & $16.4 \%$ & 673 \\
3 & $5 \%$ & $8.5 \%$ & $0.92: 0.08: 0.47$ & $20.9 \%$ & 684 & 160 \\
4 & $10 \%$ & $9.7 \%$ & $0.91: 0.09: 0.38$ & $25.6 \%$ & 704 & 126 \\
5 & $20 \%$ & $18.0 \%$ & $0.85: 0.15: 0.39$ & $13.8 \%$ & 736 & 141 \\
6 & $25 \%$ & $20.1 \%$ & $0.83: 0.17: 0.35$ & $4.3 \%$ & 801 \\
7 & $40 \%$ & $26.9 \%$ & $0.79: 0.21: 0.32$ & $1.0 \%$ & 907 & 122 \\
\hline
\end{tabular}

variety of proteins with different molecular weights and isoelectric points including lysozyme (M.W. $=14.3 \mathrm{kDa}, \mathrm{pI}=11.4)$, trypsin (M.W. $=24 \mathrm{kDa}, \mathrm{pI}=10.1)$, hemoglobin (M.W. $=64.5 \mathrm{kDa}, \mathrm{pI}=$ 6.8), and transferrin (M.W. $=80 \mathrm{kDa}, \mathrm{pI}=5.6)$. Protein-functionalized QDs were synthesized under the same conditions as BSAQDs and were characterized using agarose gel electrophoresis (SI section 4.1). Similar to BSA-QDs, QDs synthesized with all the other proteins exhibited additional QD bands with retarded mobility in the agarose gel, implying successful functionalization of QDs with these proteins. At protein concentration of $5.0 \mathrm{mg} / \mathrm{mL}$, the QDs synthesized with lysozyme, trypsin, and hemoglobin were almost completely functionalized while the QDs synthesized with transferrin were partially functionalized. Gel filtration chromatography was also used to monitor QDs functionalization. As shown in Figure 3, lysozymeQD and trypsin-QD exhibited nearly entire peak shift to larger hydrodynamic sizes, indicating almost complete QD functionalization. Two separate peaks were observed for the QDs synthesized with transferrin, which correspond to the functionalized and unfunctionalized QDs respectively. The functionalization efficiency of transferrin-QD $(5.0 \mathrm{mg} / \mathrm{mL}$ transferrin) is $47 \%$. The attachment of hemoglobin to the QDs is validated by fluorescence resonance energy transfer (FRET). Hemoglobin is an iron-containing oxygen-transport
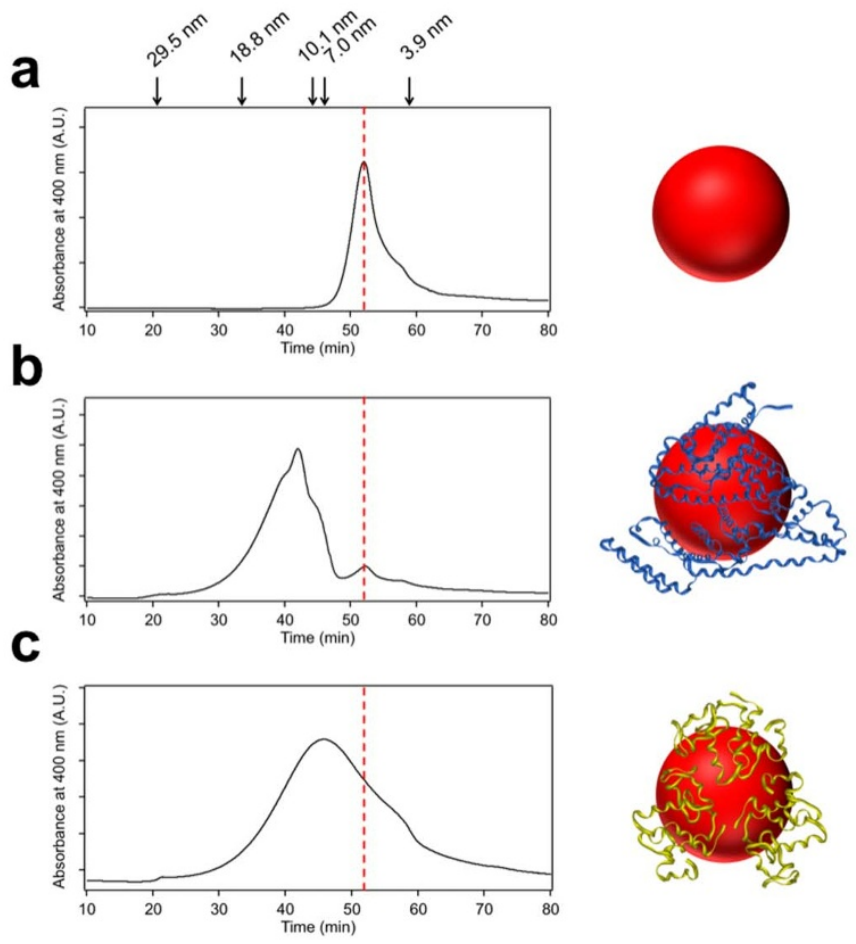

metalloprotein that exhibits strong absorption in the visible and nearIR region (SI section 4.4). Direct attachment of hemoglobin to the QD will result in efficient quenching of QD photoluminescence due to the small distance $(<5 \mathrm{~nm})$ between QD and hemoglobin. As shown in Figure 4a, with an increasing hemoglobin concentration for QD synthesis, a stepwise decrease of QD photoluminescence is observed. The quenching efficiency is $95.2 \%$ for the QDs synthesized with $5.0 \mathrm{mg} / \mathrm{mL}$ hemoglobin. To explore the impact of QDs on the biological activities of the protein, we measured the hydrolysis activities of lysozyme in native form and QD-associated form. Lysozyme activity is determined according to the lysis rate of Micrococcus lysodeikticus cells (see experimental section for more details). As shown in Figure $4 \mathrm{~b}, 88 \%$ of hydrolysis activity is preserved for the QDassociated lysozyme, suggesting that the QD binding has marginal effects on lysozyme catalytic activity.

To explore the applicability of the as-prepared $\mathrm{Zn}_{\mathrm{x}} \mathrm{Hg}_{1-\mathrm{x}} \mathrm{Se}$ QDs for bioimaging, we first tested the photostability of these $\mathrm{Zn}_{\mathrm{x}} \mathrm{Hg}_{1-\mathrm{x}} \mathrm{Se}$ QDs and compared it with the traditional CdTe QDs. The QDs were continuously excited with a high power $405 \mathrm{~nm}$ laser $(110 \mathrm{~mW})$ and their photoluminescence spectra were recorded at different time points. After $60 \mathrm{~min}$ exposure to the $405 \mathrm{~nm}$ laser, both the unfunctionalized and BSA-functionalized $\mathrm{Zn}_{\mathrm{x}} \mathrm{Hg}_{1-\mathrm{x}} \mathrm{Se}$ QDs underwent a d
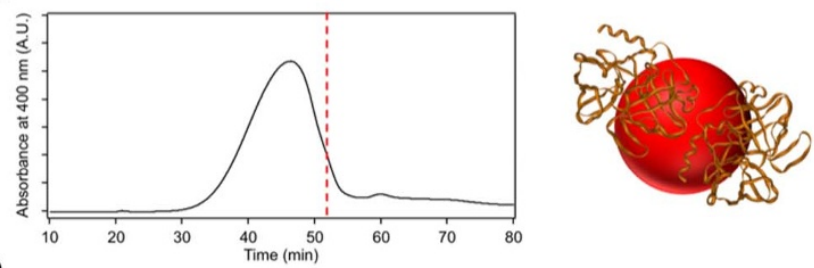

e
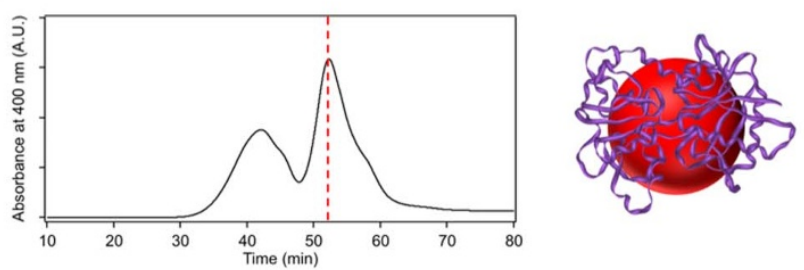

Figure 3 Gel filtration chromatography of protein-functionalized QDs. (a) Unfunctionalized MPA-QDs. Hydrodynamic diameters of sizing standards are indicated above the graph (see Supporting Information Figure S2 for more details). (b) BSA-QDs. (c) Lysozyme-QDs. (d) Trypsin-QDs. (e) Transferrin-QDs. The red dashed line in each graph indicates the peak position of MPA-QDs. 

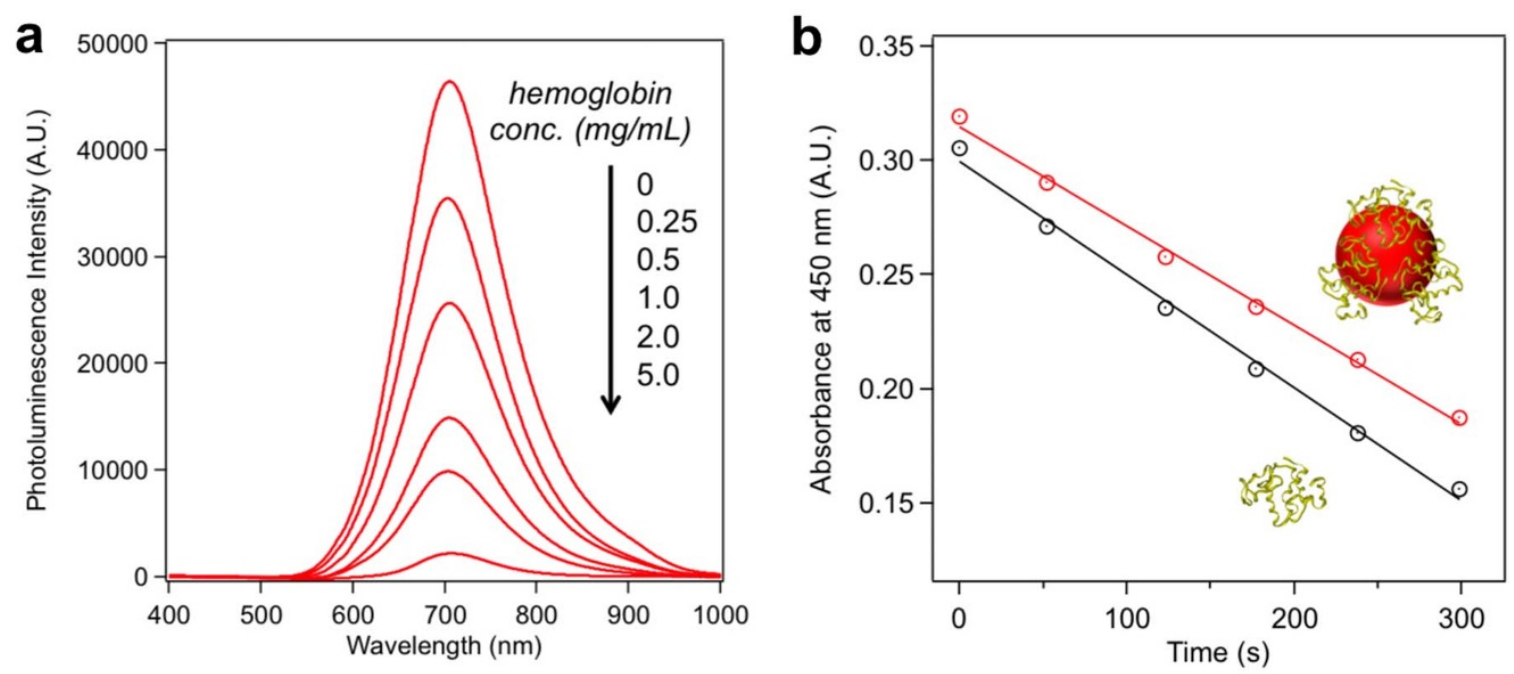

Figure $4 \mid$ Characterization of hemoglobin-QDs and lysozyme-QDs. (a) Photoluminescence quenching of $\mathrm{Zn}_{\mathrm{x}} \mathrm{Hg}_{1-\mathrm{x}} \mathrm{Se}_{\mathrm{QDs}}$ synthesized at different hemoglobin concentrations. (b) Determination of lysozyme activities in native form (black line) and QD-associated form (red line). Linear fit for native lysozyme: $y=-0.000495 x+0.299$; linear fit for QD-associated lysozyme: $y=-0.000434 x+0.315$. The slope is used to determine the lysis rate.

photobrightening effect with $54 \%$ and $51 \%$ increase of PL intensities respectively whereas the CdTe QDs were severely photobleached with $82 \%$ decrease of PL intensity (Figure $5 \mathrm{a}$ and SI section 3.3). The photobrightening effect of the as-prepared $\mathrm{Zn}_{\mathrm{x}} \mathrm{Hg}_{1-\mathrm{x}} \mathrm{Se}$ QDs is likely caused by the photo-annealing of the surface defects of the QDs. As a result, the QYs of the unfunctionalized and BSA-functionalized $\mathrm{Zn}_{\mathrm{x}} \mathrm{Hg}_{1-\mathrm{x}} \mathrm{Se}$ QDs increased to $42.5 \%$ and $41.0 \%$ after activation with the $405 \mathrm{~nm}$ laser for 1 hour. The photostability study was also performed on QDs films for $\mathrm{Zn}_{\mathrm{x}} \mathrm{Hg}_{1-\mathrm{x}}$ Se QDs and CdSe QDs under continuous excitation with a $365 \mathrm{~nm}$ UV lamp $(8 \mathrm{~W})$. The CdSe QDs were quickly photobleached after $30 \mathrm{~min}$ excitation whereas the photoluminescence of $\mathrm{Zn}_{\mathrm{x}} \mathrm{Hg}_{1-\mathrm{x}}$ Se QDs was retained even after 60 min excitation (SI section 3.3). The colloidal stability of BSA-functionalized $\mathrm{Zn}_{\mathrm{x}} \mathrm{Hg}_{1-\mathrm{x}} \mathrm{Se}$ QDs was evaluated at four different pHs $(12.3,9.0,7.4,5.2)$ during 20 days storage. Little fluctuation of QDs PL intensities, absorbance, and hydrodynamic sizes were observed for all the tested conditions, suggesting that the BSA-functionalized QDs possess robust colloidal stabilities (SI section 3.1). The non-specific cell imaging was conducted by incubating fixed HeLa cells with unfunctionalized MPA-QDs and the fluorescence images were captured on an inverted fluorescence microscope. As shown in Figure 5b, fixed HeLa cells can be readily stained with MPA-QDs showing a strong photoluminescence signal, suggesting that these $\mathrm{Zn}_{\mathrm{x}} \mathrm{Hg}_{1-\mathrm{x}} \mathrm{Se}$ QDs are well suited for cell imaging studies. When live HeLa cells were incubated with MPA-QDs no photoluminescence was detected (Figure 5b), indicating neglectable nonspecific binding of MPA-QDs with live HeLa cells which most likely results from electrostatic repulsion between the negatively charged QDs and the negatively charged cell surface ${ }^{27}$. Once the cell membrane is disrupted by cell fixation, the QDs can bind with the intracellular components of fixed cells non-specifically.

Specific cell imaging was explored using transferrin-functionalized $\mathrm{Zn}_{\mathrm{x}} \mathrm{Hg}_{1-\mathrm{x}} \mathrm{Se} \mathrm{QD}$ as a probe. Transferrin can specifically bind with transferrin receptor on cell surface and is transported into the cell via receptor-mediated endocytosis ${ }^{28}$. As shown in Figure 5b, transferrin receptor-expressing live HeLa cells incubated with transferrin-QDs exhibited strong photoluminescence signals, indicating high-level binding of transferrin-QDs with the cells. In contrast, no photoluminescence was detected for live HeLa cells incubated with BSA- QDs or MPA-QDs under the same conditions, implying that the cell binding of transferrin-QDs was specifically mediated by transferrin. The intracellular localization of transferrin-QDs is further investigated using confocal microscopy. As shown in Figure 5c, the transferrin-QDs were internalized into HeLa cells and sequestered in small vesicles. There is a high co-localization between transferrin-QDs and lysotracker, implying that the QDs uptake is mediated by endocytic pathway.

Furthermore, this QD synthetic strategy could be extended to other biomolecules such as folic acid (FA) and peptide to produce biofunctionalized QDs (Figure 6a). Folic acid has been frequently used for cancer targeting since many cancer cells overexpress folic acid receptors $^{29}$. The FA-QDs were synthesized using FA and MPA molecules as co-ligands and the reaction condition is the same as protein-functionalized QDs (see experimental for details). The presence of FA molecules on QDs was confirmed using Fourier transform infrared spectroscopy (FTIR). The characteristic IR absorption peaks of FA molecules were detected for FA-QDs but not MPA-QDs (SI section 4.5). In addition, attachment of FA molecules to QDs leads to partial quenching of QD photoluminescence. As the FA concentration increases, more pronounced QD photoluminescence quenching is observed (SI section 4.6). This quenching effect has been previously observed and is attributed to the electron transfer between FA molecules and QDs ${ }^{30}$. The FA-QDs exhibited robust colloidal stability at $\mathrm{pH} 7.4$ over 7 days storage (SI section 3.2). Live HeLa cells incubated with FA-QDs exhibited strong photoluminescence (Figure 6b), indicating highly efficient cell binding of QDs mediated by FA molecules. Next, we selected a peptide (HHHHHHCGKRK) to synthesize peptide-functionalized QDs. This peptide contains two domains including a cancer cell targeting domain (CGKRK) and a QD binding domain (HHHHHH). The tumor homing peptide CGKRK was initially identified using phage display and was found to specifically bind to MDA-MB-435 human breast cancer cell line ${ }^{31}$. The QD binding domain contains six histidine residues that are known to strongly coordinate with $\mathrm{Zn}^{2+}$ ions and have been utilized for QD bioconjugation ${ }^{13}$. The peptide-functionalized $\mathrm{Zn}_{\mathrm{x}} \mathrm{Hg}_{1-\mathrm{x}} \mathrm{Se}$ QDs were synthesized using the peptide and MPA molecules as co-ligands. The presence of peptide molecules on QDs was confirmed by agarose gel electrophoresis (SI section 4.1). Moreover, we found that the peptide itself (HHHHHHCGKRK or $\mathrm{HHHHHH)} \mathrm{can} \mathrm{mediate} \mathrm{the} \mathrm{growth} \mathrm{of} \mathrm{Zn}_{\mathrm{x}} \mathrm{Hg}_{1-\mathrm{x}} \mathrm{Se}$ QDs in the absence of MPA molecules (SI section 2.3), suggesting that the QD synthesis and functionalization can be achieved in a single step. This is distinct from the previous study showing that the oligohistidine can be attached to the pre-synthesized QDs via histidine-zinc interaction $^{16}$. As shown in Figure 6b, live MDA-MB-435S cells incubated with peptide QDs exhibited strong photoluminescence as a result of efficient QD binding. In contrast, no photoluminescence signal was 

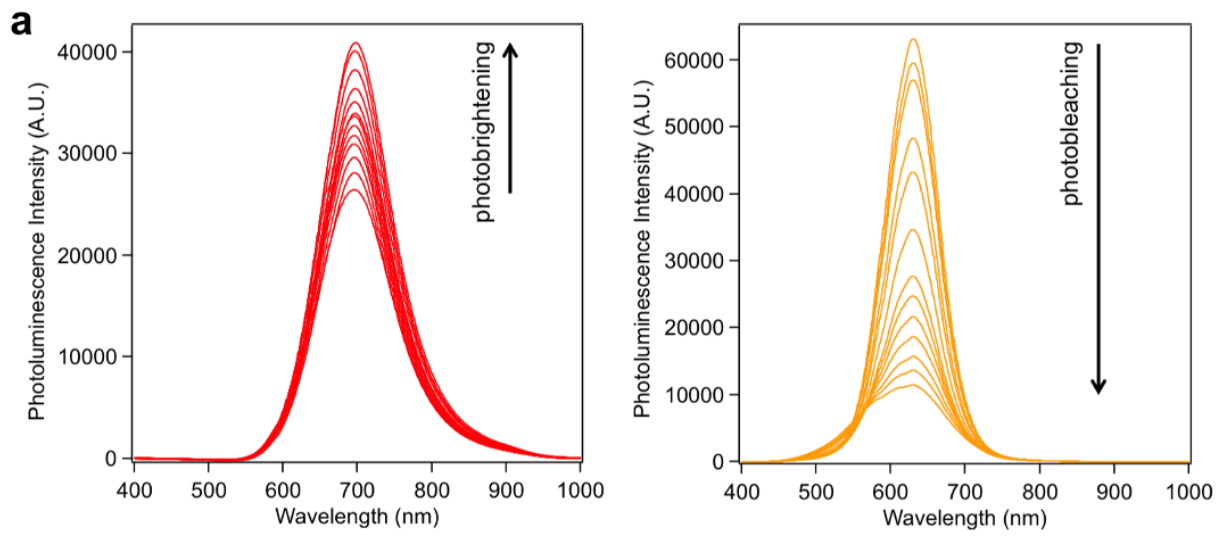

b
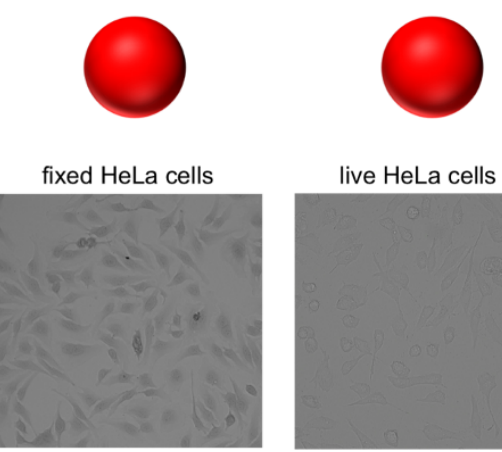

live HeLa cells
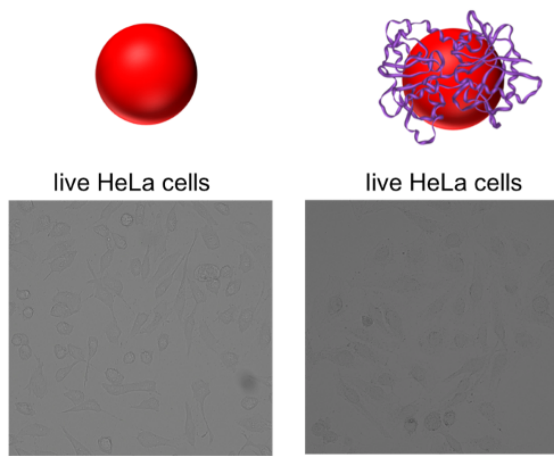

live HeLa cells
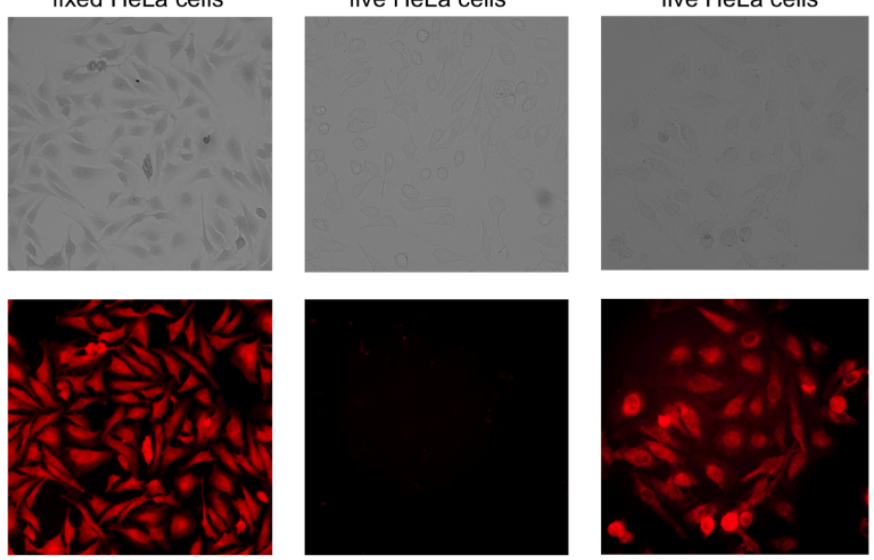

C
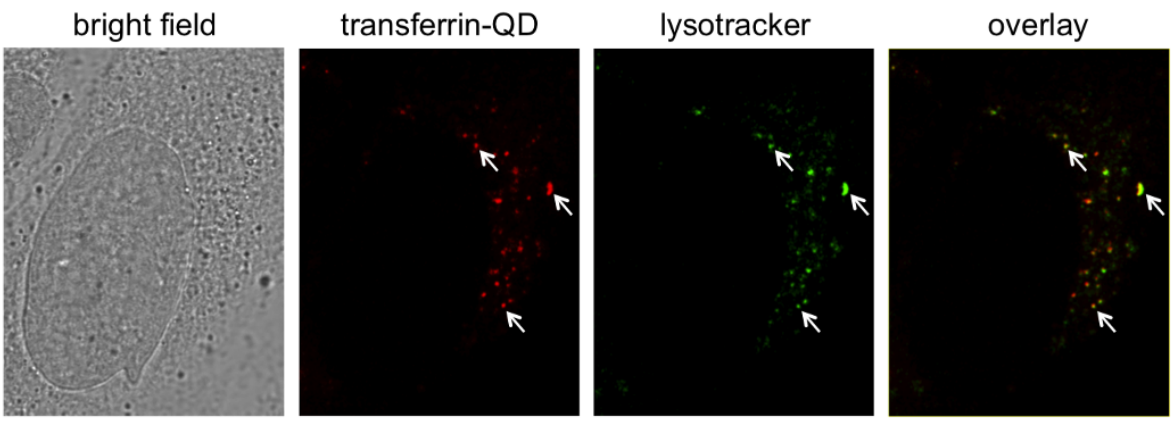

Figure $5 \mid \mathrm{Zn}_{\mathrm{x}} \mathrm{Hg}_{1-\mathrm{x}} \mathrm{Se}$ QDs for cell imaging. (a) Photostability measurements of unfunctionalized $\mathrm{Zn}_{\mathrm{x}} \mathrm{Hg}_{1-\mathrm{x}} \mathrm{Se}$ QDs and CdTe QDs. Both QDs were continuously excited with a $405 \mathrm{~nm}$ laser $(110 \mathrm{~mW})$ and the photoluminescence spectra were recorded at different time points $(0,0.5,1,3,5,8,12,15,20$, 30, 40, 50, $60 \mathrm{~min}$ ) (b) Bright field and fluorescence images of cells incubated with $\mathrm{Zn}_{\mathrm{x}} \mathrm{Hg}_{1-\mathrm{x}} \mathrm{Se}$ QDs. From left to right: fixed HeLa cells with MPA-QDs; live HeLa cells with MPA-QDs; live HeLa cells with transferrin-QDs; live HeLa cells with BSA-QDs. The images were acquired with a $10 \times$ objective. See Supplementary Information (section 4.5) for the fluorescence image acquired with a 40× objective which shows punctate patterns of cell staining. (c) Bright field and confocal fluorescence microscopy image of a singe HeLa cell incubated with transferrin-QDs (red) and Lysotracker Green DND-26. The overlay image shows a high co-localization between the QDs and lysotracker. (Representative regions of overlap are indicated by arrows.)

detected for live MDA-MB-435S cells incubated with unfunctionalized MPA-QDs, suggesting that the cell binding of peptide-QD was specifically mediated by the peptide.

\section{Discussion}

We present a general facile strategy for one-step synthesis of biofunctionalized QDs. The reaction can be conducted in aqueous solution at ambient conditions and completed within one second. The as-prepared biofunctionalized $\mathrm{Zn}_{\mathrm{x}} \mathrm{Hg}_{1-\mathrm{x}} \mathrm{Se}$ QDs exhibit strong photoluminescence, high photostability and can be used for specific cell targeting and imaging. The reported strategy to construct biofunctionalized QDs is much more straightforward than the traditional synthetic routes. We expect that this QDs synthesis strategy would be accessible to any laboratory that needs fluorescence labeling of biomolecules. 
a

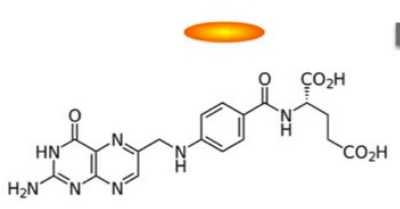

Folic acid

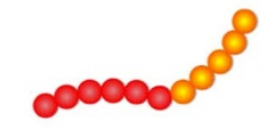

Peptide (HHHHHHCGKRK)

b

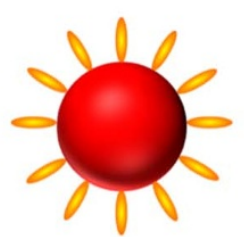

live HeLa cells

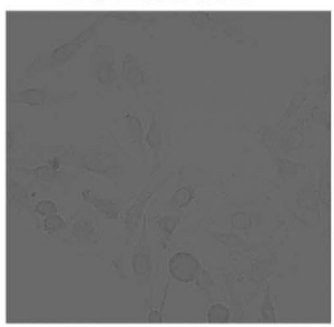

live MDA-MB-435S cells
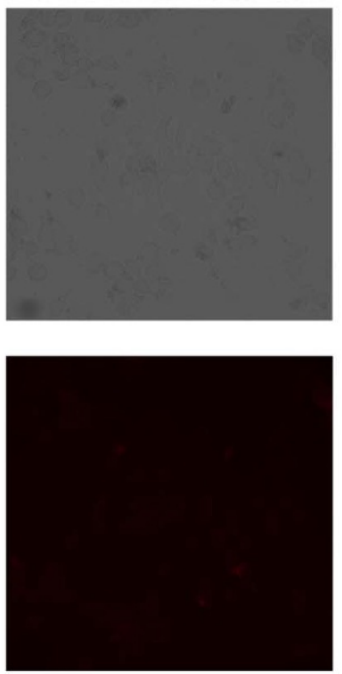

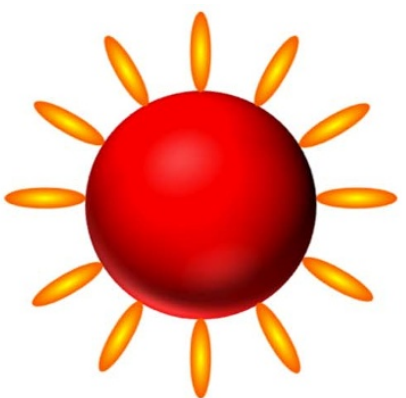

Folic acid-QD
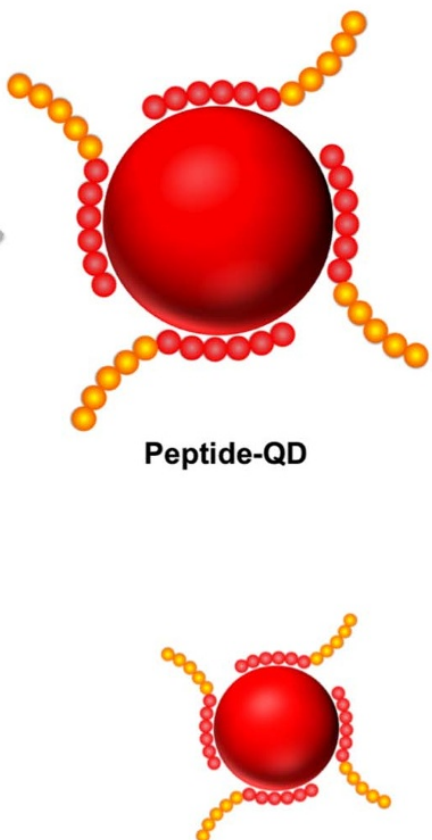

live MDA-MB-435S cells
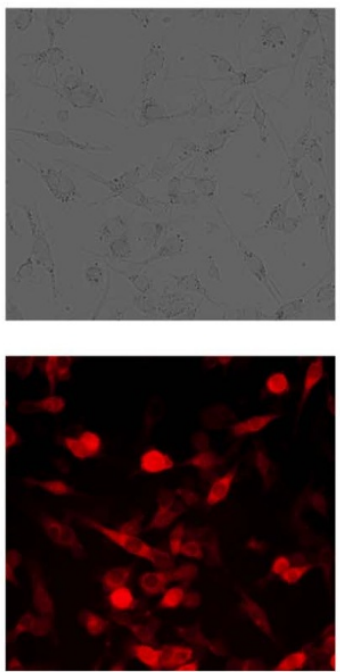

Figure $6 \mid$ Construction of folic acid- and peptide-functionalized $\mathrm{Zn}_{\mathrm{x}} \mathrm{Hg}_{1-\mathrm{x}} \mathrm{Se}$ QDs for cell imaging. (a) Schematic illustration of folic acid-QDs and peptide-QDs prepared in one-step synthesis. (b) Bright field and fluorescence images of cells incubated with $\mathrm{Zn}_{\mathrm{x}} \mathrm{Hg}_{1-\mathrm{x}} \mathrm{Se}$ QDs. From left to right: live HeLa cells with folic acid-QDs; live MDA-MB-435S cells with MPA-QDs; live MDA-MB-435S cells with peptide-QDs. The peptide sequence is HHHHHHCGKRK. The images were acquired with a $10 \times$ objective.

\section{Methods}

Materials. Zinc acetate dihydrate (99.0\%), mercaptopropionic acid (MPA, 99\%), selenium powder $(99.99 \%)$, tellurium powder $(99.997 \%)$, cadmium chloride (99.99\%), sodium borohydride $(98.0 \%)$, sodium selenite $(98.0 \%)$, Coomassie brilliant blue R-250 (dye content $\sim 50 \%$, technical grade), albumin from bovine serum, hemoglobin from bovine blood, lysozyme from chicken egg white, TPCK treated trypsin from bovine pancreas, transferrin from human, insulin, and Micrococcus Lysodeikticus were purchased from Sigma-Aldrich. Mercuric perchlorate (99.0\%) was 
purchased from Strem Chemicals. Ammonium hydrogen carbonate $\left(\mathrm{NH}_{4} \mathrm{HCO}_{3}\right.$, $\mathrm{AR})$, sodium hydroxide ( $\mathrm{NaOH}, \mathrm{AR})$, acetic acid (AR), hydrochloric acid ( $\mathrm{HCl}, \mathrm{GR})$, nitric acid $\left(\mathrm{HNO}_{3}, \mathrm{GR}\right)$, bromophenol blue (AR), potassium bromide (AR) and folic acid (FA, BR) were purchased from Sinopharm Chemical Reagent Co., Ltd. Agarose powder was purchased from Biowest. Glycerol and tris(Hydroxymethyl) aminomethane (Tris) were purchased from Beijing Solarbio Science \&Technology Co., Ltd. Lysotracker Green DND-26 was purchased from Invitrogen. Phosphate buffered saline (10× PBS) was purchased from Thermo Scientific (HyClone).

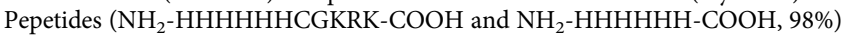
were purchased from ChinaPeptides Co., Ltd (Shanghai, China). HeLa cells were purchased from China Center for Type Culture Collection (CCTCC). MDA-MB$435 \mathrm{~S}$ cells were purchased from Cell Resource Center of Shanghai Institutes for Biological Sciences, Chinese Academy of Sciences. Dulbecco's Modified Eagle's Medium (DMEM), fetal bovine serum (FBS), $0.25 \%$ trypsin/EDTA and phosphate buffered saline (PBS) were purchased from Hyclone. Leibovitz medium (L-15) was obtained from Gibco. Water used in all the studies was purified with a Milli-Q water purification system. All other reagents and solvents were of analytical grade.

Synthesis of unfunctionalized, protein-functionalized, folic acid-functionalized, and peptide-functionalized $\mathbf{Z n}_{\mathbf{x}} \mathbf{H g}_{1-\mathrm{x}} \mathrm{Se}$ QDs. Se precursor (250 mM NaHSe) was prepared by reducing $0.0197 \mathrm{~g}$ selenium powder with $0.0200 \mathrm{~g}$ sodium borohydride in $1 \mathrm{~mL}$ water at room temperature. The reaction was finished after complete dissolution of selenium powder to form a colorless solution.

To synthesize unfunctionalized $\mathrm{Zn}_{\mathrm{x}} \mathrm{Hg}_{1-\mathrm{x}} \mathrm{Se}$ QDs, $\left.125 \mu \mathrm{L} \mathrm{Zn(OAc)}\right)_{2}(100 \mathrm{mM})$, desired volume $(1.25,2.5,6.25,12.5$ or $25 \mu \mathrm{L})$ of $\mathrm{Hg}\left(\mathrm{ClO}_{4}\right)_{2}(100 \mathrm{mM})$, and $37.5 \mu \mathrm{L}$ MPA $(500 \mathrm{mM})$ were added to $\mathrm{NH}_{4} \mathrm{HCO}_{3}$ solution $(0.2 \mathrm{M}, \mathrm{pH}=12.3$ adjusted by $10 \mathrm{M} \mathrm{NaOH}$ solution) to a total volume of $500 \mu \mathrm{L}$. Then $25 \mu \mathrm{L} \mathrm{NaHSe}(250 \mathrm{mM})$ was quickly injected into the precursor solution above followed by gently vortexing. The reaction solution turned brown immediately after adding NaHSe, indicating instant formation of $\mathrm{Zn}_{\mathrm{x}} \mathrm{Hg}_{1-\mathrm{x}} \mathrm{Se}$ QDs.

To synthesize protein-functionalized $\mathrm{Zn}_{\mathrm{x}} \mathrm{Hg}_{1-\mathrm{x}} \mathrm{Se} \mathrm{QDs}$, protein stock solution $(100 \mathrm{mg} / \mathrm{mL})$ was first prepared by dissolving protein powder (BSA, lysozyme, trypsin, hemoglobin, and transferrin) in $1 \times$ PBS. For QD synthesis, desired amount of protein (final concentration: $0,0.25,0.5,1.0,2.0$ or $5.0 \mathrm{mg} / \mathrm{mL}$ ) was added together with $125 \mu \mathrm{L} \mathrm{Zn}(\mathrm{OAc})_{2}(100 \mathrm{mM}), 12.5 \mu \mathrm{L} \mathrm{Hg}\left(\mathrm{ClO}_{4}\right)_{2}(100 \mathrm{mM})$, and $37.5 \mu \mathrm{L}$ MPA $(500 \mathrm{mM})$ to $\mathrm{NH}_{4} \mathrm{HCO}_{3}$ solution $(0.2 \mathrm{M}, \mathrm{pH}=12.3)$ to a total volume of $500 \mu \mathrm{L}$. Then $25 \mu \mathrm{L}$ NaHSe $(250 \mathrm{mM})$ was quickly injected into the precursor solution above followed by gently vortexing. The reaction solution turned to brown immediately after adding NaHSe, indicating instant formation of $\mathrm{Zn}_{\mathrm{x}} \mathrm{Hg}_{1-\mathrm{x}} \mathrm{Se}$ QDs.

The synthesis protocol of folic acid and peptide-functionalized $\mathrm{Zn}_{\mathrm{x}} \mathrm{Hg}_{1-\mathrm{x}} \mathrm{Se}$ QDs is same as protein-functionalized $\mathrm{Zn}_{\mathrm{x}} \mathrm{Hg}_{1-\mathrm{X}} \mathrm{Se} \mathrm{QDs}$ except that protein stock solution was replaced by folic acid stock solution and peptide stock solution, respectively. Folic acid stock solution $(250 \mathrm{mM})$ was prepared by dissolving folic acid in $\mathrm{NH}_{4} \mathrm{HCO}_{3}$ solution $(0.2 \mathrm{M}, \mathrm{pH}=12.3)$. Peptide stock solution $(100 \mathrm{mM})$ was prepared by dissolving the peptide $\left(\mathrm{NH}_{2}\right.$ - $\left.\mathrm{HHHHHHCGKRK-COOH}\right)$ in $\mathrm{H}_{2} \mathrm{O}$. To synthesize folic acid-functionalized $\mathrm{Zn}_{\mathrm{x}} \mathrm{Hg}_{1-\mathrm{x}} \mathrm{Se}$ QDs, $0,2,5,10,20,50 \mu \mathrm{L}$ folic acid stock solution were added for a $500 \mu \mathrm{L}$ synthesis. To synthesize peptide-functionalized $\mathrm{Zn}_{\mathrm{x}} \mathrm{Hg}_{1-\mathrm{x}} \mathrm{Se}$ QDs, $0,15.5,31.25,62.5 \mu \mathrm{L}$ peptide stock solution were added for a $500 \mu \mathrm{L}$ synthesis.

Synthesis of CdTe QDs. Te precursor (NaHTe) was prepared by reducing $0.0400 \mathrm{~g}$ tellurium powder with $0.0250 \mathrm{~g}$ sodium borohydride in $1 \mathrm{~mL}$ water at $60^{\circ} \mathrm{C}$ for 40 minutes. To synthesize CdTe QDs, $6.25 \mu \mathrm{L} \mathrm{CdCl}_{2}$ solution $\left(100 \mathrm{mM}\right.$ in $\left.\mathrm{H}_{2} \mathrm{O}\right)$ and $1.25 \mu \mathrm{L}$ MPA solution $\left(500 \mathrm{mM}\right.$ in $\left.\mathrm{H}_{2} \mathrm{O}\right)$ were added to $\mathrm{NH}_{4} \mathrm{HCO}_{3}$ solution $(0.2 \mathrm{M}$, $\mathrm{pH}=8.5$ adjusted by $10 \mathrm{M} \mathrm{NaOH}$ solution) to a total volume of $500 \mu \mathrm{L}$. Then $0.5 \mu \mathrm{L}$ Te precursor was swiftly injected into the reaction mixture. The reaction was conducted at $100^{\circ} \mathrm{C}$ for 2 hours.

Optical characterization. QD samples were first purified via centrifugation at $6000 \mathrm{rpm}$ for $3 \mathrm{~min}$ to remove any insoluble precipitation, and the supernatant QDs solution was collected for the measurements. The photoluminescence spectra were recorded using a fiber fluorescence spectrophotometer (AvaSpec-ULS2048-USB2) equipped with a $405 \mathrm{~nm}$ laser $(110 \mathrm{~mW})$ as excitation light source. The integration time was set to $20 \mathrm{~ms}$. The absorption spectra were recorded using a UV-Vis spectrophotometer (Agilent 8453). Pure $\mathrm{NH}_{4} \mathrm{HCO}_{3}$ solution $(0.2 \mathrm{M}, \mathrm{pH}=12.3)$ was used as a blank for baseline correction.

QD elemental analysis. $50 \mu \mathrm{L} \mathrm{Zn}_{\mathrm{x}} \mathrm{Hg}_{1-\mathrm{x}} \mathrm{Se} \mathrm{QD}$ samples prepared with different $\mathrm{Hg} /$ $\mathrm{Zn}$ precursor ratios were first diluted to $500 \mu \mathrm{L}$ with $\mathrm{H}_{2} \mathrm{O}$ and then purified with Microsep ${ }^{\mathrm{TM}}$ Advance Centrifugal Devices (YM-3, Pall Corporation) via centrifugation at $13500 \mathrm{rpm}$ for $5 \mathrm{~min}$ to remove any free precursors. The purification was repeated twice. The purified QDs were recovered to $500 \mu \mathrm{L}$ with $\mathrm{H}_{2} \mathrm{O}$ and then digested with $1 \mathrm{~mL}$ concentrated $\mathrm{HNO}_{3}$ at $90^{\circ} \mathrm{C}$ for 3 hours. The digested solution was diluted to $5 \mathrm{~mL}$ with $\mathrm{H}_{2} \mathrm{O}$. Quantitative elemental analysis of zinc, mercury, and selenium in each sample was performed on an inductively coupled plasma optical emission spectrometer (Varian 710-ES). A dilution series of zinc acetate, mercuric perchlorate, and sodium selenite solutions with known concentrations were made to generate standard curves.

TEM characterization. A few drops of each QD sample were dispersed onto a $3 \mathrm{~mm}$ copper grid covered with a continuous carbon film and were dried at room temperature. TEM characterization was performed using a JEOL JEM-2100 transmission electron microscope operating at $200 \mathrm{kV}$. STEM-EELS measurements were performed on a Tecnai G2 F20 S-Twin (FEI) transmission electron microscope.

Quantum yield determination. The QY is calculated according to the equation below:

$$
\Phi_{x}=\Phi_{s t}\left(I_{x} / I_{s t}\right)\left(\eta_{x}^{2} / \eta_{s t}{ }^{2}\right)\left(A_{s t} / A_{x}\right)
$$

Where $\Phi$ is the quantum yield, $I$ is the measured integrated emission intensity, $\eta$ is the refractive index of the solvent, and $A$ is the optical density. The subscript " $s t$ " refers to standard with known quantum yield and " $x$ " refers to the QD sample. Fluorescence spectra were measured under $490 \mathrm{~nm}$ excitation. Rhodamine $6 \mathrm{G}$ (QY $=95 \%$ in ethanol) was chosen as the standard.

Photostability measurements of $\mathrm{Zn}_{\mathrm{x}} \mathrm{Hg}_{1-\mathrm{x}} \mathrm{Se}$ QDs, CdTe QDs, and CdSe QDs. Unfunctionalized $\mathrm{Zn}_{\mathrm{x}} \mathrm{Hg}_{1-\mathrm{x}} \mathrm{Se}$ QDs, BSA-functionalized $\mathrm{Zn}_{\mathrm{x}} \mathrm{Hg}_{1-\mathrm{x}} \mathrm{Se}$ QDs, and CdTe QDs $\left(\lambda_{\text {em }}=630 \mathrm{~nm}\right)$ were freshly prepared according to the protocol described above. QD samples were continuously excited with a $405 \mathrm{~nm}$ laser $(110 \mathrm{~mW})$ and the fluorescence spectra were record at different time points $(0,0.5,1,3,5,8,12,15,20,30$, 40, 50, $60 \mathrm{~min}$ ). Photostability studies were peformed on QDs films for CdSe QDs and $\mathrm{Zn}_{\mathrm{x}} \mathrm{Hg}_{1-\mathrm{x}} \mathrm{Se}$ QDs. The QD films were continuously excited with a $365 \mathrm{~nm}$ UV lamp ( $8 \mathrm{~W})$ for $30 \mathrm{~min}$ and $60 \mathrm{~min}$ and the fluorescence images were recorded on an Olympus IX71 epifluorescence microscope with 1 millisecond acquisition time.

Colloidal stability measurements of $\mathrm{Zn}_{\mathrm{x}} \mathrm{Hg}_{1-\mathrm{x}} \mathrm{Se}$ QDs. The $\mathrm{pH}$ of BSAfunctionalized $\mathrm{Zn}_{\mathrm{x}} \mathrm{Hg}_{1-\mathrm{x}} \mathrm{Se}$ QDs solution was adjusted with $0.1 \mathrm{M} \mathrm{HCl}$ to the desired value $(12.3,9.0,7.4,5.2)$ and then the QDs were stored at room temperature. The photoluminescence spectra, absorption spectra, and DLS data were recorded after 0 , $1,2,3,5,7,10,15,20$ days. The $\mathrm{pH}$ of FA-QDs was adjusted to 7.4 with $0.1 \mathrm{M} \mathrm{HCl}$ and then the QDs were stored at room temperature. The photoluminescence spectra, absorption spectra, and DLS data were recorded after 0, 1, 3, 5, 7 days.

Unfunctionalized $\mathrm{Zn}_{\mathrm{x}} \mathrm{Hg}_{1-\mathrm{x}} \mathrm{Se}$ QDs were diluted 10 times in $1 \times \mathrm{PBS}$ and stored at room temperature. The photoluminescence spectra were recorded after $0,1,2,3,7$, $10,15,20$ days.

Agarose gel electrophoresis. $2 \mu \mathrm{L}$ QD sample was mixed with $8 \mu \mathrm{L} \mathrm{NH}_{4} \mathrm{HCO}_{3}$ solution $(0.2 \mathrm{M}, \mathrm{pH}=12.3)$ and $2 \mu \mathrm{L} 6 \times$ agarose loading buffer and then loaded into $1 \%$ agarose gel. $1 \times \mathrm{TA}$ buffer (Tris/acetic acid) was used as the running buffer. The gel was run for $25 \mathrm{~min}$ at a constant voltage of $120 \mathrm{~V}$ and then imaged on a UV transilluminator of the UVP GelDoc-It 310 Imaging System with an excitation wavelength of $365 \mathrm{~nm}$. The gel was subsequently stained with $0.1 \%$ Coomassie brilliant blue R-250 in 30\% methanol and 10\% acetic acid for $1 \mathrm{~h}$ and destained in $50 \%$ ethanol and $10 \%$ acetic acid for $24 \mathrm{~h}$ in an orbital shaker (TS-1, QILINBEIER) with the speed of $80 \mathrm{rpm}$ before digital image acquisition.

Gel filtration chromatography. Gel filtration chromatography was performed using a Superose ${ }^{\mathrm{TM}} 6$ 10/300 GL column (GE Healthcare) conjugated to an Agilent 1260 Infinite HPLC system. Before running, each sample was purified via centrifugation at $10000 \mathrm{rpm}$ for $5 \mathrm{~min}$ to remove any insoluble aggregates. The flow rate was fixed at $0.35 \mathrm{~mL} / \mathrm{min}$, the injection volume was $80 \mu \mathrm{L}$ and each sample was run for an overall time of $80 \mathrm{~min}$. The absorption wavelength used to monitor QDs was set at $400 \mathrm{~nm}$. $1 \times$ PBS ( $\mathrm{pH}$ 7.4) was used as the running buffer. For nanocrystals sizing, a protein standards solution was prepared to include $15 \mu \mathrm{L}$ blue dextran $(25 \mathrm{mg} / \mathrm{mL}), 35 \mu \mathrm{L}$ thyroglobulin $(25 \mathrm{mg} / \mathrm{mL}), 15 \mu \mathrm{L}$ alcohol dehydrogenase $(25 \mathrm{mg} / \mathrm{mL}), 25 \mu \mathrm{L}$ BSA $(25 \mathrm{mg} / \mathrm{mL})$, and $10 \mu \mathrm{L}$ lysozyme $(25 \mathrm{mg} / \mathrm{mL})$.

Dynamic light scattering. Dynamic light scattering (DLS) measurements were performed on a Zetasizer Nano ZS90 (Malvern) with $90^{\circ}$ scattering angle and a $\mathrm{He}-\mathrm{Ne}$ laser.

Purification of $\mathrm{Zn}_{\mathbf{x}} \mathrm{Hg}_{1-\mathrm{x}} \mathrm{Se}$ QDs. The QDs were first centrifuged at $10000 \mathrm{rpm}$ for $5 \mathrm{~min}$ to remove any insoluble aggregates and then purified with a Microsep ${ }^{\mathrm{TM}}$ Advance Centrifugal Devices (Pall Corporation) via centrifugation at $13500 \mathrm{rpm}$ for $5 \mathrm{~min}$ to remove unreacted precursors and free ligand molecules. The selection of the molecular weight cut-off of the centrifugal device is dependent on the size of the ligands for QD synthesis. $3 \mathrm{kD}$ cut-off filters are used to purify MPA-QDs, FA-QDs, and peptide-QDs; $30 \mathrm{kD}$ cut-off filters are used to purify lysozyme-QDs; $100 \mathrm{kD}$ cutoff filters are used to purify BSA-QDs and transferrin-QDs.

Circular dichroism spectrum. CD spectra of native BSA and QD-associated BSA were recorded on a circular dichroism spectrometer (Aviv Model-410, Biomedical). $3 \mathrm{~mL}$ of each sample was added into a $1 \mathrm{~cm}$ quartz cell and measured at the scan speed of $50 \mathrm{~nm} / \mathrm{min}$ with a bandwidth of $2 \mathrm{~nm}$. During the measurements the voltage of PMT detector of the CD spectrometer was maintained below $500 \mathrm{~V}$.

Lysozyme activity measurements. The lysozyme activity was determined by the lysis rate of Micrococcus lysodeikticus. Lysozyme-capped $\mathrm{Zn}_{\mathrm{x}} \mathrm{Hg}_{1-\mathrm{x}} \mathrm{Se} \mathrm{QDs}$ were first purified with a Microsep ${ }^{\mathrm{TM}}$ Advance Centrifugal Device (YM-30, Pall Corporation) via centrifugation at $13500 \mathrm{rpm}$ for $5 \mathrm{~min}$ to remove free lysozyme. The purification step was repeated twice. The purified QDs were then recovered in $1 \times$ PBS buffer to the initial volume. For each assay $0.05 \mathrm{mg}$ Micrococcus lysodeikticus in $0.1 \mathrm{~mL} 1 \times$ PBS was added into a flat transparent Corning 96-well plate, after which $0.1 \mathrm{~mL}$ native lysozyme $(10 \mu \mathrm{g} / \mathrm{mL})$ or lysozyme-capped QDs (lysozyme concentration 
$10 \mu \mathrm{g} / \mathrm{mL}$ ) was added into the well containing Micrococcus lysodeikticus and quickly mixed. The absorbance of each sample at $450 \mathrm{~nm}$ was recorded using a multifunctional microplate reader (Tecan Infinite M200 Pro) every 60 seconds. The absorbance was plotted against the reaction time for the native lysozyme sample and the lysozyme-QD sample respectively. The ratio of the slopes for these two linear fits provides the percentage of remained lysozyme activity for the QD-associated lysozyme.

Fourier transform infrared spectroscopy (FTIR) characterization. Folic acidfunctionalized $\mathrm{Zn}_{\mathrm{x}} \mathrm{Hg}_{1-\mathrm{x}} \mathrm{Se} \mathrm{QDs}$ were synthesized as described above. The QD sample was purified with a Microsep ${ }^{\mathrm{TM}}$ Advance Centrifugal Device (YM-3, Pall Corporation) via centrifugation at $13500 \mathrm{rpm}$ for $5 \mathrm{~min}$ to remove free folic acid molecules, and the purification step was repeated twice. The purified QDs were then recovered in $\mathrm{H}_{2} \mathrm{O}$ to the initial volume and then concentrated using a rotary evaporator (RE52CS-1, Shanghai Yarong) and dried in a hot oven (GZX-9030MBE Shanghai Boxun). The QDs powder was mixed with potassium bromide 1:50 (w/w), grinded, and compressed into tablets. The infrared spectrum was recorded on a Fourier transform infrared spectrophotometer (Varian ProStar LC240). Folic acid and unfunctionalized QDs were used as controls

Fixed cell imaging with unfunctionalized $\mathrm{Zn}_{\mathbf{x}} \mathrm{Hg}_{1-\mathrm{x}} \mathrm{Se}$ QDs. HeLa cells were cultured on $25 \mathrm{~cm}^{2}$ cell culture plates with vent caps (Corning) in DMEM supplemented with $10 \%$ fetal bovine serum in a humidified incubator at $37^{\circ} \mathrm{C}$ containing $\mathrm{CO}_{2}(5 \%)$. HeLa cells that had been grown to subconfluence were dissociated from the surface with a solution of $0.25 \%$ trypsin/EDTA for $1 \mathrm{~min}$. Then aliquots ( $500 \mu \mathrm{L}, 5 \times 10^{4}$ cells) were seeded into a 24 -well plate (Corning). After overnight incubation, the cells were fixed with $200 \mu \mathrm{L}$ cold anhydrous methanol (stored at $-20^{\circ} \mathrm{C}$ before experiment) for $15 \mathrm{~min}$, then washed three times with PBS The QDs were first purified with a Microsep ${ }^{\mathrm{TM}}$ Advance Centrifugal Device (YM-3, Pall Corporation) via centrifugation at $13000 \mathrm{rpm}$ for $5 \mathrm{~min}$ and then recovered with $\mathrm{NH}_{4} \mathrm{HCO}_{3}$ solution $(0.2 \mathrm{M}, \mathrm{pH}=12.3)$ to the initial volume. The purified QDs were then diluted 1:2 with $1 \times$ PBS. The fixed HeLa cells were incubated with $120 \mu \mathrm{L}$ diluted QDs for $30 \mathrm{~min}$ at room temperature and then washed twice with $1 \times$ PBS. The photoluminescence images were captured on an Olympus IX 71 inverted fluorescence microscope with 330-385 nm mercury lamp excitation and the QD emission signal was collected with a $420 \mathrm{~nm}$ long-pass filter.

Specific live cell imaging with transferrin, folic acid, and peptide-functionalized $\mathbf{Z n}_{\mathbf{x}} \mathbf{H g}_{1-\mathbf{x}}$ Se QDs. HeLa cells were cultured and seeded as described above. MDAMB-435S cells were cultured on $25 \mathrm{~cm}^{2}$ cell culture plates with vent caps (Corning) in L-15 medium supplemented with $10 \%$ fetal bovine serum and $0.01 \mathrm{mg} / \mathrm{mL}$ insulin in a humidified incubator at $37^{\circ} \mathrm{C}$. MDA-MB- 435 cells that had been grown to subconfluence were dissociated from the surface with a solution of $0.25 \%$ trypsin/ EDTA for $2 \mathrm{~min}$. Then aliquots $\left(500 \mu \mathrm{L}, 5 \times 10^{4}\right.$ cells $)$ were seeded into a 24 -well plate (Corning). After overnight incubation, the cells were washed once with $1 \times \mathrm{PBS}$. Transferrin, folic acid, and peptide-functionalized $\mathrm{Zn}_{\mathrm{x}} \mathrm{Hg}_{1-\mathrm{x}} \mathrm{Se}$ QDs were first purified with a Microsep ${ }^{\mathrm{TM}}$ Advance Centrifugal Device (YM-3, Pall Corporation) via centrifugation at $13000 \mathrm{rpm}$ for $5 \mathrm{~min}$ and then recovered with $\mathrm{NH}_{4} \mathrm{HCO}_{3}$ solution $(0.2 \mathrm{M}, \mathrm{pH}=12.3)$ to the initial volume. The purified QDs were then diluted $1: 2$ with $1 \times \mathrm{PBS}$ and the $\mathrm{pH}$ was adjusted to $7 \sim 8$ with diluted $\mathrm{HCl}$. For transferrin and folic acid-functionalized QDs, HeLa cells were incubated with $120 \mu \mathrm{L}$ diluted QDs at $37^{\circ} \mathrm{C}$ for 1 hour and then washed twice with $1 \times$ PBS. For peptide-functionalized QDs, MDA-MB-435S cells were incubated with $120 \mu \mathrm{L}$ diluted QDs at $37^{\circ} \mathrm{C}$ for 1 hour and then washed twice with $1 \times$ PBS. Unfunctionalized QDs were used as a negative control for all the studies. The photoluminescence images were captured on an Olympus IX 71 inverted fluorescence microscope with $10 \times$ and $40 \times$ objectives with 330-385 nm mercury lamp excitation and the QD emission signal was collected with a $420 \mathrm{~nm}$ long-pass filter.

Confocal microscopy. Live cells were incubated with the QDs sample at $37^{\circ} \mathrm{C}$ for $1 \mathrm{~h}$ and washed twice with $1 \times$ PBS. After that the cells were incubated with $100 \mu \mathrm{L}$ Lysotracker Green DND-26 solution (1:1000 diluted in serum-free cell culture medium) for $20 \mathrm{~min}$ and washed three times with $1 \times$ PBS. Confocal microscopy was performed on a Leica TCS SP5 II confocal laser scanning microscope using a $63 \times$ oil immersion objective. Localization of QDs was visualized with $405 \mathrm{~nm}$ diode laser excitation and the emission signal was collected between 650 and $750 \mathrm{~nm}$.

Localization of Lysotracker Green DND-26 was visualized with $476 \mathrm{~nm}$ argon laser excitation and the emission signal was collected between $500 \mathrm{~nm}$ and $600 \mathrm{~nm}$.

1. Alivisatos, A. P. Semiconductor clusters, nanocrystals, and quantum dots. Science 271, 933-937 (1996).

2. Bruchez Jr., M., Moronne, M., Gin, P., Weiss, S. \& Alivisatos, A. P. Semiconductor nanocrystals as fluorescent biological labels. Science 281, 2013-2016 (1998).

3. Chan, W. C. W. \& Nie, S. Quantum dot bioconjugates for ultrasensitive nonisotopic detection. Science 281, 2016-2018 (1998).

4. Michalet, X. et al. Quantum dots for live cells, in vivo imaging, and diagnostics. Science 307, 538-544 (2005).

5. Medintz, I. L., Uyeda, H. T., Goldman, E. R. \& Mattoussi, H. Quantum dot bioconjugates for imaging, labeling and sensing. Nature Mater. 4, 435-446 (2005).

6. Kim, S. et al. Near-infrared fluorescent type II quantum dots for sentinel lymph node mapping. Nat. Biotechnol. 22, 93-97 (2004).
7. Jaiswal, J. K., Mattoussi, H., Mauro, J. M. \& Simon, S. M. Long-term multiple color imaging of live cells using quantum dot bioconjugates. Nat. Biotechnol. 21, 47-51 (2003).

8. So, M.-K., Xu, C., Loening, A. M., Gambhir, S. S. \& Rao, J. Self-illuminating quantum dot conjugates for in vivo imaging. Nat. Biotechnol. 24, 339-343 (2006).

9. Medintz, I. L. et al. Proteolytic activity monitored by fluorescence resonance energy transfer through quantum-dot-peptide conjugates. Nature Mater. 5, 581-589 (2006)

10. Resch-Genger, U., Grabolle, M., Cavaliere-Jaricot, S., Nitschke, R. \& Nann, T Quantum dots versus organic dyes as fluorescent labels. Nature Methods $\mathbf{5}$ 763-775 (2008)

11. Howarth, M. et al. Monovalent, reduced-size quantum dots for imaging receptors on living cells. Nature Methods 5, 397-399 (2008).

12. Choi, H. S. et al. Design considerations for tumour-targeted nanoparticles. Nat. Nanotechnol. 5, 42-47 (2010).

13. Medintz, I. L. et al. Self-assembled nanoscale biosensors based on quantum dot FRET donors. Nat. Mater. 2, 630-638 (2003).

14. Murray, C. B., Norris, D. J. \& Bawendi, M. G. Synthesis and characterization of nearly monodisperse $\mathrm{CdE}(\mathrm{E}=\mathrm{S}, \mathrm{Se}, \mathrm{Te})$ semiconductor nanocrystallites. J. Am. Chem. Soc. 115, 8706-8715 (1993).

15. Wu, X. et al. Immunofluorecent labeling of cancer marker Her2 and other cellular targets with semiconductor quantum dots. Nat. Biotechnol. 21, 41-46 (2003).

16. Liu, W. et al. Compact biocompatible quantum dots functionalized for cellular imaging. J. Am. Chem. Soc. 130, 1274-1284 (2008)

17. Ma, N., Marshall, A. F. \& Rao, J. Near-infrared light emitting luciferase via biomineralization. J. Am. Chem. Soc. 132, 6884-6885 (2010).

18. Zhao, L. et al. Organophosphorus acid anhydrolase bio-template for the synthesis of CdS quantum dots. Chem. Commun. 47, 7242-7244 (2011).

19. Goswami, N. et al. Protein-directed synthesis of NIR-emitting, tunable $\mathrm{HgS}$ quantum dots and their applications in metal-ion sensing. Small 8, 3175-3184 (2012).

20. Ma, N., Sargent, E. H. \& Kelley, S. O. Biotemplated nanostructures: directed assembly of electronic and optical materials using nanoscale complementarity. J. Mater. Chem. 18, 954-964 (2008).

21. Ma, N., Sargent, E. H. \& Kelley, S. O. One-step DNA-programmed growth of luminescent and biofunctionalized nanocrystals. Nat. Nanotechnol. 4, 121-125 (2009).

22. Tikhomirov, G. et al. DNA-based programming of quantum dot valency, selfassembly and luminescence. Nat. Nanotechnol. 6, 485-490 (2011).

23. Peelle, B. R., Krauland, E. M., Wittrup, K. D. \& Belcher, A. M. Design criteria for engineering inorganic material-specific peptides. Langmuir 21, 6929-6933 (2005).

24. Trzaskowski, B., Adamowicz, L. \& Deymier, P. A. A theoretical study of zinc (II) interactions with amino acid models and peptide fragments. J. Biol. Inorg. Chem. 13, 133-137 (2008)

25. Smith, A. M. \& Nie, S. Bright and compact alloyed quantum dots with broadly tunable near-infrared absorption and fluorescence spectra through mercury cation exchange. J. Am. Chem. Soc. 133, 24-26 (2011).

26. Janin, J. Surface and inside volumes in globular proteins. Nature 277, 491-492 (1979).

27. Grazu, V., Moros, M. \& Sanchez-Espinel, C. Nanobiotechnology: Inorganic Nanoparticles vs Organic Nanoparticles Ch. 14 (Elsevier, Oxford 2012).

28. Hopkins, C. R. \& Trowbridge, I. S. Internalization and processing of transferrin and the transferrin receptor in human carcinoma A431 cells. J. Cell. Biol. 97, 508-521 (1983)

29. Low, P. S., Henne, W. A. \& Doorneweerd, D. D. Discovery and development of folic-acid-based receptor targeting for imaging and therapy of cancer and inflammatory diseases. Acc. Chem. Res. 41, 120-129 (2008).

30. Zhang, Y., Liu, J.-M. \& Yan, X.-P. Self-assembly of folate onto polyethyleneiminecoated CdS/ZnS quantum dots for targeted turn-on fluorescence imaging of folate receptor overexpressed cancer cells. Anal. Chem. 85, 228-234 (2013).

31. Hoffman, J. A. et al. Progressive vascular changes in a transgenic mouse model of squamous cell carcinoma. Cancer Cell 4, 383-391 (2003).

\section{Acknowledgements}

This work was supported in part by National Science Foundation of China (21175147), the Recruitment Program of Global Young Experts (1000-Young Talents Plan), the Project of Scientific and Technologic Infrastructure of Suzhou (SZS201207), the Priority Academic Program Development of Jiangsu Higher Education Institutions (PAPD), and startup funds from Soochow University.

\section{Author contributions}

X.H. and N.M. conceived and designed the experiments; X.H. and L.G. performed the experiments; X.H., L.G. and N.M. analyzed the data; N.M. wrote the manuscript.

\section{Additional information}

Supplementary information accompanies this paper at http://www.nature.com/ scientificreports 
Competing financial interests: The authors declare no competing financial interests.

How to cite this article: He, X., Gao, L. \& Ma, N. One-Step Instant Synthesis of

Protein-Conjugated Quantum Dots at Room Temperature. Sci. Rep. 3, 2825; DOI:10.1038/ srep02825 (2013). cc) (i) $\odot$ This work is licensed under a Creative Commons AttributionBY NC ND NonCommercial-NoDerivs 3.0 Unported license. To view a copy of this license, visit http://creativecommons.org/licenses/by-nc-nd/3.0 